ISSN: 2238-8052

\title{
PORTRAITS OF CATANIA CITY IN THE CIVITATES ORBIS TERRARUM OF BRAUN AND HOGENBERG: THE “LOCAL” MODEL (SIXTEENTH CENTURY)
}

\author{
RETRATOS DA CIDADE DE CATANIA NO CIVITA DO ORBIS TERRARUM DE BRAUN E \\ HOGENBERG: O MODELO "LOCAL" (SÉCULO XVI)
}

\section{Keywords:} Early Modern History Urban History History of Cartography Sicily Identities

Palavras-chave: História Moderna História Urbana História da Cartografia Sicília Identidades

\begin{abstract}
A B S T R A C T
This work is part of a research project on the processes of the formation of urban identities. It attempts to reconstruct the role that images and descriptions have played in the process, using Catania as a case study. In this article we will examine, by way of municipal history and iconography, the process of constructing a "portrait" of the city (a map/view) linked to the need to "construct" an all-encompassing view, an identity: a map-view published in Amsterdam in 1598 and included in the 5th volume of Braun and Hogenberg's Civitates Orbis Terrarum, clearly drew on a "local" model, a map printed on behalf of the Catanian Antonio Stizzia in Rome in 1592.
\end{abstract}

\section{R E S U M O}

Este trabalho faz parte de um projeto de pesquisa sobre os processos de formação de identidades urbanas. Ele tenta reconstruir o papel que as imagens e as descrições têm desempenhado no processo, usando Catania como um estudo de caso. Neste artigo, examinaremos, por meio da história e iconografia municipais, o processo de construção de um "retrato" da cidade (um mapa / visão) vinculado à necessidade de "construir" uma visão abrangente, uma identidade: um mapa-panorâmico publicado em Amsterdã em 1598 e incluído no 5o volume de Civitates Orbis Terrarum de Braun e Hogenberg, claramente desenhou um modelo "local", um mapa impresso em nome do Catanian Antonio Stizzia em Roma em 1592.

\section{1. “CATANA URBS ... AD RADICES AETNAE, CUI SUBEST, EXTENDITUR”}

A map-view published in Amsterdam in 1598 and included in the 5th volume of Braun and Hogenberg's Civitates Orbis Terrarum (picture 1) ${ }^{2}$ would serve the purpose of a Europe an cartographic laudatio of Catania in the 16th century. It is clearly drawn on a map printed on behalf of the Catanian Antonio Stizzia in Rome in 1592 (picture 2), whose engraver, apart from small changes, just embellishes the drawing.

\footnotetext{
1 Professore ordinario of Early Modern History at the Department of Scienze umane of the University of Catania. E-mail: iachello@unict.it.

${ }^{2}$ Anastatic reprint edited by R.A. Skelton, Amsterdam, 1965, XL. Thanks to Giuseppe Pagnano for the valuable indications. On Braun and Hogenberg, cf. J. Bagrow and R.A. Skelton, History of Cartography, London, 1964, ad voces.
} 
Picture 1 - Catana Urbs Siciliae Clarissima Patria S. Agathae Virginis et Mart., s.a. e s.d., in G. braun e F. Hogenberg, Civitates Orbis Terrarum, V, Coloniae Agrippinae 1597, incisione su rame, mm. 370x505

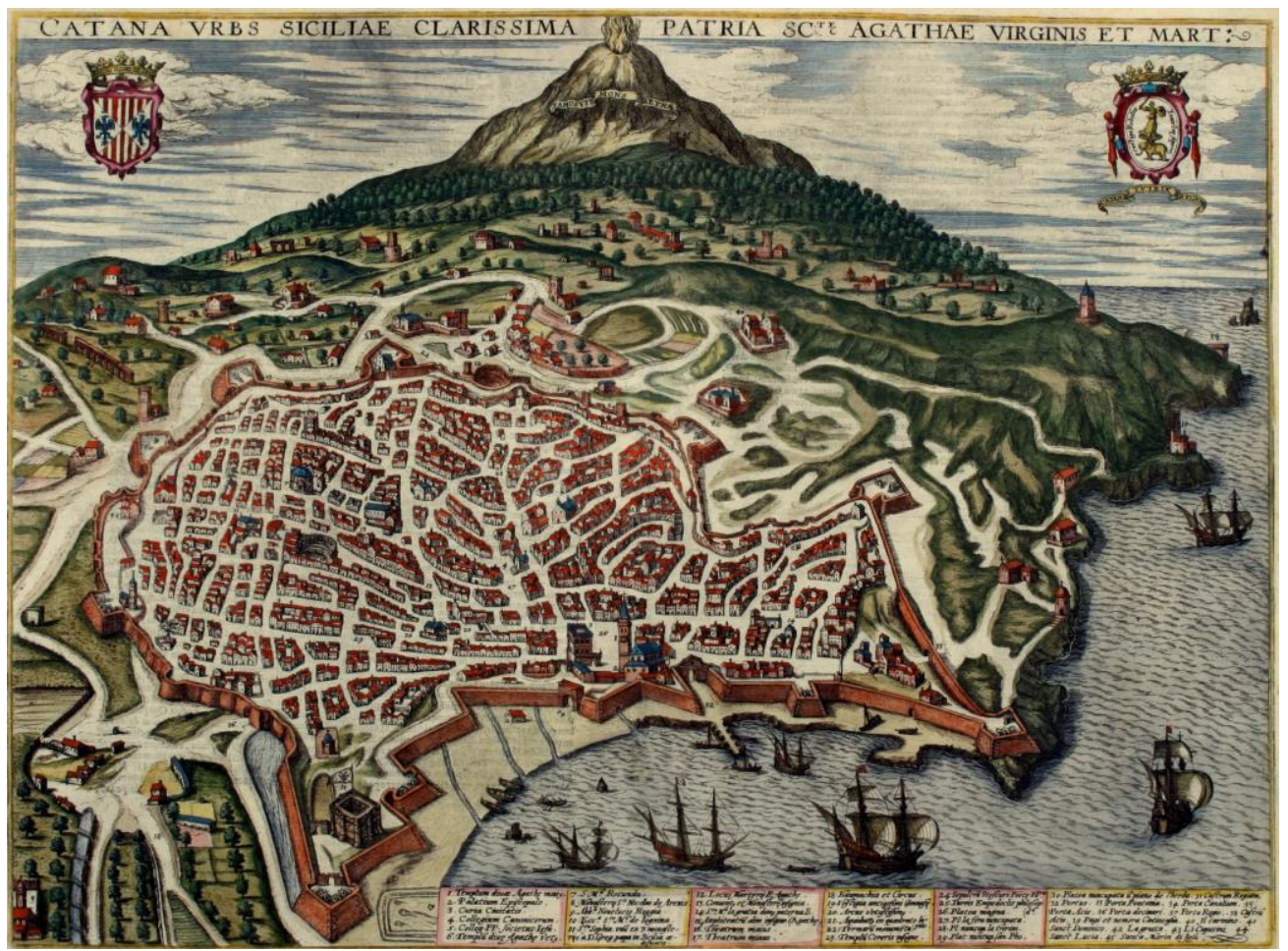

Picture 2 - La clarissima Città di Catania Patria di S.ta Agatha Verg. Et Mar., nicola Van Aelst, Roma 1592 , incisione su rame, $\mathrm{mm} 522 \times 380$

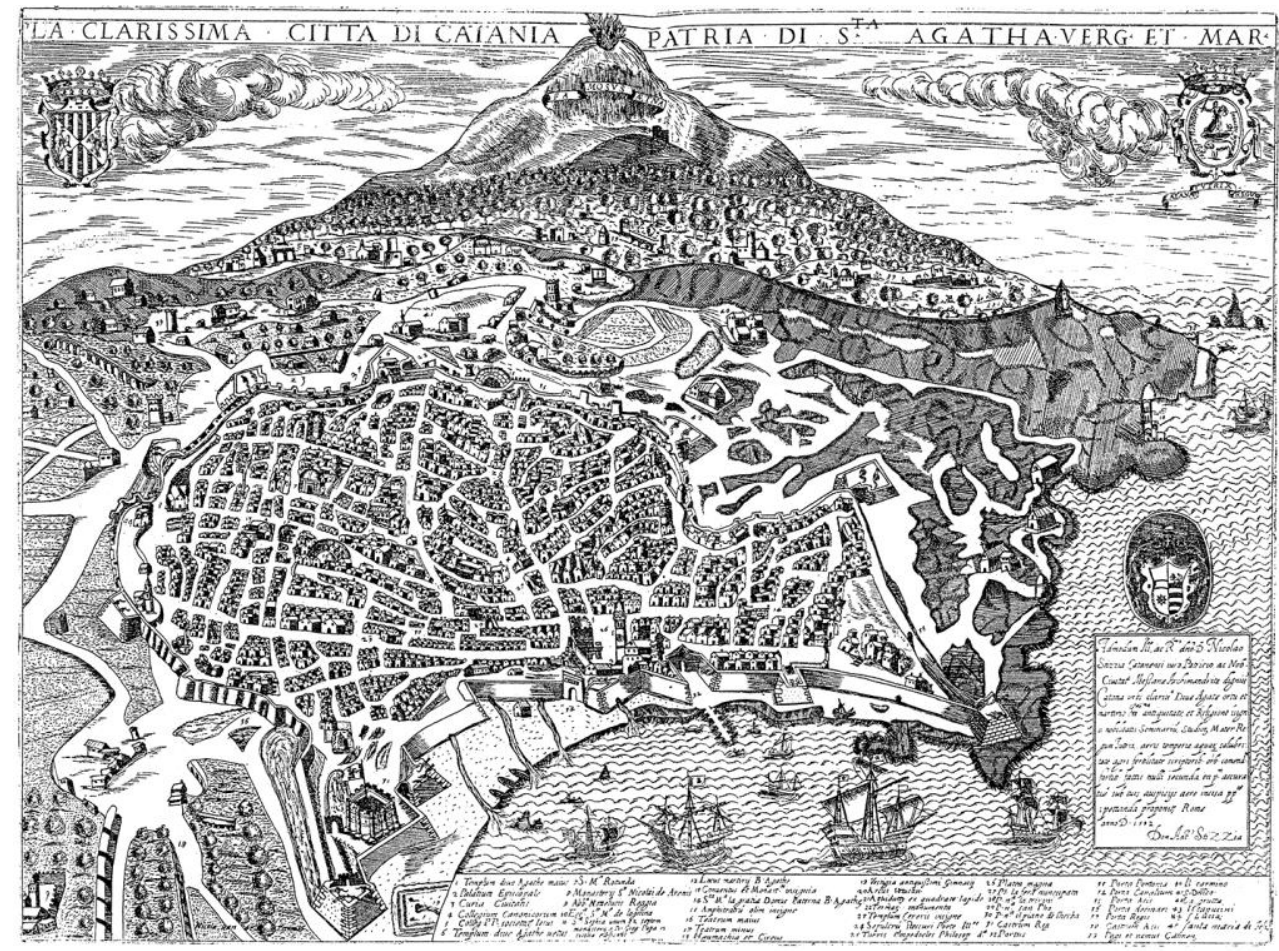


Before dealing with this model (as it will be for the majority of the subsequent representations), in order to clarify better the 16th century development of the image of Catania, it is convenient, though, to examine another map-view which has remained unpublished for a long time and was commissioned by Angelo Rocca during his stay in Catania in 1584 (picture 3) ${ }^{3}$. This map is part of a project of an unpublished - but almost ready for printing - atlas by the Augustinian bishop Rocca who had profited from his visitationes to the kingdom of Naples and Sicily between 1583 and 1584 to collect maps of the cities of the two kingdoms ${ }^{4}$. The Augustinian bishop had also prepared a questionnaire for the local authorities which would serve as a model of representation strictly connected with the local journalism of the day. The questionnaire begins with a "Brief description of the city [...] taken partly from the Archives of the Communities, in some particular history or some memory of the ancient and partly in the tradition of the ancestors" ${ }^{\prime 5}$. The theme (the description of the city) is accompanied by a very ample indication of the possible sources which in general are those usually used by the scholars of the time and, to make a Sicilian example, by Tommaso Fazello6. The connections with these scholars become evident when Rocca would ask for a long list of information ending with the request for the "Disegno di città" for the wealth of details both of the urban map and of the surrounding territory: the Etnean region. The legend shows a long list of the important urban centres from whose arrangement a representative hierarchy emerges, this being confirmed by the evidence of the image to which the letters and the numbers refer8.

In this hierarchy the primacy goes to the places of worship or, anyway, to the religious places: the churches (from A., S. Agata "the mother church", to I, except C, the Castle), the monasteries and the convents (from 11 to 28), the special churches (from 38 to 73). The "civil" places are the castle, the ramparts (whose identification, from 1 to 10 , is made through the names of the saints, by emphasizing the pre-eminence of the religious element), the piazzas and the markets (from 74 to 80). Separate emphasis is given to the past of the city: the remains of the ancient vestiges (from 81 to 89).

\footnotetext{
${ }^{3}$ About this view, s. N. Muratore and P. Munafò (eds.), Immagini di città raccolte da un frate agostiniano alla fine del XVI secolo, Roma, 1991.

${ }^{4}$ Muratore and Munafò, Immagini di città, 11. Angelo Rocca was in Catania on the 15 th of April and from the 17 th to the 27 th of June, 1584 (ibid., 19).

5 [“Brieve descrittione delle città [...] da trovarsi parte dagli Archivi delle Communità, da qualche historia particolare o da qualche memoria degli antichi e parte per tradittione de' predecessor."].

6 On Tommaso Fazello cf. R. Contarino, Fazello Tommaso, in Dizionario Biografico degli Italiani, Roma, 1995, entry 45, 493496.

7 Ibid.

8 Ibid., 176-177.
} 
Picture 3. Catania, s.a. e s.d., disegno a penna su carta, mm 580x427 (Biblioteca Angelica - Roma)

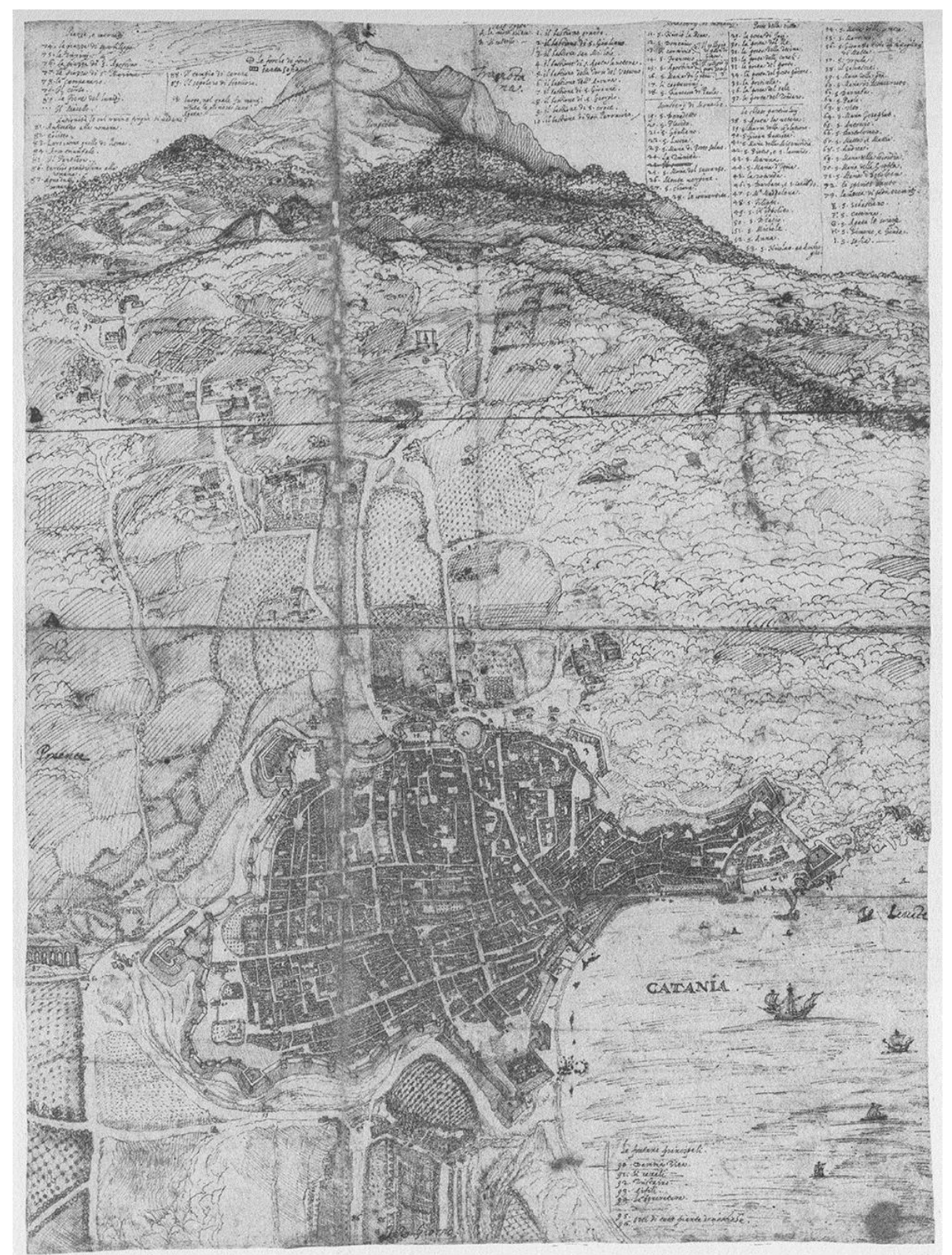

The Augustinian bishop's view of the city (which was reproduced halfway between the perspective and the military axonometric projection) is thus expressed in an iconographic manner. It emphasizes the role of the church and of the religious orders in the process of identification of the urban space characterized by an intricate road network. From it, though, some important routes, which might have been highlighted in the typically 16th century attempt to give "rationality" and symmetry to the represented space ${ }^{9}$, emerge as more consistent vacuums in the plenum of the inhabited areas. The forma urbis draws a sort of circle with two arms of different lengths stretching

${ }^{9}$ Cf. D. Calbi, Storia della città. L'età moderna, Venezia, 2001, 27. 
towards the sea, the right arm hinting at a wharf outstretched towards numerous boats. Thick vegetation descends from Etna close to the city walls eastwards and is separated by a thick lava arm beyond which the outlines of the Etnean farmhouses can be seen. On the other hand, both at the centre of the map, where the "forche di fora" 10 stand out and on its western side there are, following one another and facing the ramparts which rise up all around the city, the cultivated fields, they being graphically the most prominent element through which the city draws and differentiates its perimeter in the place which houses and feeds it.

Indeed, more than the city, the view emphasizes the Etnean fields and woods, and offers a much more detailed drawing compared with the perfunctory conical representation of the tops of the volcano and of the sloping down of its sides.

In this imposition of the presence of the volcano there is the desire to meet the expectations of the European learned society - do not forget that the aim was to insert the map in an atlas - towards a phenomenon which had always aroused a great interest resulting in a considerable accumulation of descriptions and quotations which would reoccur from one century to the next. Up to the point that Fazello ${ }^{11}$ would feel the need to point out that Mount Etna "is so well-known for the fame of its eruptions, for the tales of its poets and for the works of the historians and of the philosophers that to write at length about it would be pointless rather than necessary"12, except that he would then contradict himself knowing well that the reader would be disappointed if he had not dwelled upon this "marvel" at length.

But before Fazello, and to remain roughly within the period near to the map which is being dealt with, in 1496 Pietro Bembo's De Aetna almost provided an ample synthesis of the Etnean mythology ${ }^{13}$.

That mountain is amazing for its position, its shape, its size, its fertility and its eruptions, and, in short, it is by far the greatest for all its uniqueness and beauty, and it is without equal. To the east it touches the Ionian Sea and right at the bottom of its foothills it supports Catania ... Etna spreads its roots as in a circle ... The lowest slopes and the foothills all around are densely covered in castles and villages: the land is rich in the gifts of Bacchus, Pallas and Ceres; very rich, more than it is possible to believe, in all sorts of herds. Around that area, in every place, there are here very pleasant spots, there roaring rivers, there rumbling streams, there very icy perennial springs, there the land is always adorned with constantly blooming flowers.

10 "forche di fora" are scaffolds placed outside the city [Translator's note].

11 T. Fazello, De Rabus Siculis [...], Palermo, 1558. For the Italian translation, T. Fazello, Della storia di Sicilia deche due del R.P.M. Tommaso Fazello siciliano tradotte in lingua toscana dal P.M. Remigio Fiorentino, Palermo, 1817, has been used.

12 Fazello, De Rebus Siculis, I, 2, 149. ['è tanto noto per la fama dei suoi fuochi, per le favole de' poeti, e per gli scritti degl'istorici, e de' filosofi, che lo scriverne lungamente sarebbe cosa più tosto superflua, che necessaria"].

13 P. Bembo, De Aetna, Palermo, 1981; Venezia, 1496, 70. [“Quel monte per la posizione, la forma, la grandezza, la fertilità e le eruzioni, è stupefacente, e insomma per tutta la sua singolarità e bellezza è di gran lunga eccelso, e non ha eguali. A oriente lambisce il mare Jonio e proprio al fondo del suo piede soregge Catania ... L'etna allarga le sue radici quasi incerchio ... I declivi più bassi e le falde tutte in giro sono fittamente popolati di castelli e villaggi: la terra è ricca dei doni di Baco, di Pallade, di Cerere; ricchissima più che non si creda di armenti di ogni genere. Lì intorno, per ogni dove, siti amenissimi, lì scroscianti fiumi, lì ruscelli rumoreggianti, lì gelidissime sorgenti perenni, lì la terra è sempre ornata di fiori in continua primavera."]. 
Fazello will stress the prodigious features and elements by explaining the surprising fertility of "Catania's vineyards" scientifically (starting from the indications that had been provided by many observers in the early 16 th century):

These stones, in time, ... becoming dust make the soil, which is extremely fertile, fat. This is why all that region is pleasant and adorned with beautiful vineyards and all sorts of cultivated fruits, and the lands that are there yield great forage. Besides, this country is so rich in pastures that if the cattle that graze there were not helped by taking blood out of their ears, their feeding and grazing would be dangerous ${ }^{14}$.

If in 1598 Catania would appear in Braun-Hoenberg's atlas, if the map by Stizzia (who would record the celebration of this fame - "Famosus Aetna", then "Famosus Mons Aetna" in the Civitates - in the roll under the volcano) would be accepted as the archetype in it, it is due, in all likelihood, to the volcano.

Between Rocca's and Stizzia's maps the differences are considerable and, on the other hand, to compare them can aim to identify unlikely (if not impossible, Rocca's map being - as we said unpublished) direct connections between them. Some basic similarities emerge, though, which refer not only to the culture of the day, but also to a shared perception - we believe - of the identity of the city as it would gradually develop and become popular locally at the end of the 16th century. The first common element is represented by the fact that the lines of the drawing of the walls are emphasized and their perimeter is left incomplete in the first map - which is here more reliable ${ }^{15}$ - whereas it is perfectly closed all around the inhabited area in the second map, so as to almost confirm the old rule that a city is defined, above all, by its walls and their presence. But the most important element the two views have in common is the choice of perspective: in both the maps the city is seen from the sea so as to be placed under the volcano. This perspective, with a few variations, was destined to be cartographically successful, because, on the one hand, (above all, we would say) it was the result of a "local" choice, that is, it emerged in the processes of the development of the urban identity carried out by the Catanian élite which would receive maintenance from the Etnean region, even though some tragic events might be recorded in the city's relationship with the volcano; rather, just because of those events, this same élite would develop - as we will see - a strategy of co-existence - which would also create a mythology - able to exorcize the catastrophic perceptions deriving from its position. On the other hand, because it would meet, as it has been said, the great curiosity - not only mythological and religious, but also literary, scientific and geographic - which has been always aroused by the volcano.

\footnotetext{
14 Fazello, De Rebus Siculis, I, 2, 150. ["Questi sassi in successo di tempo ... risolvendosi in polvere fanno una terra grassa, la quale è fecondissima. Di qui nasce, che tutta quella regione è tutta amena, ornata di bellissime vigne, e d'ogni specie di frutti domestici, e le campagne che vi sono, producono biade bellissime. E' questo paese in oltre tanto abbondante di pascoli, che se il bestiame che vi pasce non fusse ajutato con trargli sangue dagli orecchi, il mangiar loro, ed il pascersi sarebbe pericoloso."].

15 G. Pagnano, Il disegno delle difese. L'eruzione del 1669 e il riassetto delle fortificazioni di Catania, Catania, $1992,19$.
} 
Just as will occur for the travel writing, the success of the image and the development of the descriptions into topoi derive, also here, from the interaction between the "local" view and the external "curiosity/expectations". Like Houel in his Voyage en Sicile ${ }^{16}$ in the 18th century will be guided by Prince Biscari, in the 16th century the cartographers Braun and Hogenberg would let themselves be guided by the Catanian nobleman Antonio Stizzia. He is the one, as it has been said, who, in Rome, requested that the Flemish engraver Nicola van Aelst ${ }^{17}$ make the map "accuratissime sub ... auspicijs aere incise" by "Don Nicolao Stizzia Catanensi viro Patricio ac Nobile", Archimandrite of Messina (whose coat of arms is reproduced ${ }^{18}$ ) and to whom it is dedicated.

The dedication reveals that the map was due to the initiative of an important family of the urban Catanian nobility and becomes precious for us in order to understand the context and the aims of the commission. In 1582 Nicola Stizzia, being a judge of the court of the Royal Monarchy would be requested by the viceroy Marc'Antonio Colonna to deal with a dispute between the bishop and the Senate regarding the rights over some land, had declared himself in favour of the the Senate ${ }^{19}$. We are, thus, brought back to the controversy in which, during all the second half of the 16th century, the Senate of Catania and the Bishop would dispute the control over the Etnean farmhouses and woods, which, significantly, are indicated collectively and claimed as "pagi et nemora catinensia".

The choices made for the representation are clarified by the municipal pride and the celebratory purpose in the dedication. "Catania urbs clarissima - we read - Divae Agate ortu et martirio, Illustrissima antiquitate et Religione insignis nobilitatis Seminarium Studiorum Mater Regum Tutrix aerris temperie aquarium salubritate agri fertilitate scriptoribus orbis comendata fortibus fattis [sic] nulli secunda". The elements of the laudatio, which will be represented in the view, are, thus, summarized. In the first place there is the city's claim for Sant'Agata, who was then also claimed by Palermo, this being almost a response to Fazello who hadn't take sides in his narrative ${ }^{20}$. This claim is repeated in the frame where the "Illustrious City of Catania" is defined as "Homeland of the Virgin and Martyr Saint Agatha". The coat of arms of the city - which is reproduced beside the top of the volcano, on the right-hand side - with the armed Saint on the elephant emphasizes this strong element of identity. The coat of arms of the Spanish Sicily and the roll under the coat of arms with the Saint ("Catania tutrix regum", a motto being repeated, as it has been seen, in the dedication) emphasize the relationship with the crown as a declaration of loyalty but also as one of effective support. This latter

\footnotetext{
16 J. Houel, Voyage pittoresque des isles de Sicile, de Malte et de Lipari, Paris, 1782-1787.

17 For information on Nicolas Van Haelst (1527 ca - 1613), s. R.V. Tooley, Tooley's Dictionary of Mapmakers, New York, 1979 , 5 and Saur. Allgemeines Künstler-Lexicon, München - Leipzig, 1992, I, 440.

18 Stizzia Catanensis ex senatorio ordine [...] primus fuit in Regno Siciliae ordinarius Judex (ut dicunt) Monarchiae ... an. vero 1593 episcopus Cephalaedensis [...] decessit e vita 17 feb. An. 1595 (R. Pirro, Sicilia Sacra, Palermo, 1733, 817).

${ }_{19}$ M. Gaudioso, La questione demaniale in Catania e nei "casali" del bosco etneo. Il vescovo-barone, Catania 1971, 39.

20 Fazello, De Rebus Siculis, I, 3, 137.
} 
element being missing in Rocca's map, who would consider the religious places as primary elements in the identification of the urban space, it emphasizes here the civil purpose from which the map originated. Near the Cathedral the "curia civitatis" (which is not indicated in Rocca's legend) is represented and referred to in the numbered legend, it, too, being significantly out of scale, like the cathedral.

The view is inscribed in a pentagon with its western side being a little longer, in which everything seems to converge towards the top of the mountain whose smoke comes out of the frame, so as to graphically emphasize its power.

Unlike Rocca's map, here the body of the city expands towards the Etnean region thus making the distance from the volcano shorter, so as to emphasize their bond through proximity.

To link the city to the volcano and make this view of the overlooking mountain possible, the author uses various perspectives by superimposing them in the drawing itself. The topographic relief of an axonometric type used for the urban map, with a strong perspective distortion, is inserted into a panoramic view which represents the overlooking volcano. The visual device aims at establishing, precisely, connections between the city and its location. An imaginary line joins the bell tower of the cathedral, which is placed in the lower part of the map and stands out against all the buildings, with the smoking top.

The description made by the Dominican Fazello thus becomes an image. The author of the $D e$ Rebus Siculis had explained the etymology of the name of the city in this way: "There are many people who claim that this name should come from its position, and that it is called like that because it is placed under the mountain: because the Greek word Catana means placed under the top in our language" 21 .

And his description would start in this way: "One part of this city of Catania is on the sea, the others face the foothills of Mount Etna, under which it is placed"22.

"Radices" is a key word in order to understand the relationship of the city with the volcano which builds/destroys the city with its powerful displays.

We are facing an urban representation which shows that it has solved the problems which even questioned the city being placed at the foot of the volcano in the mid 16th century, when the viceroy Gonzaga had advised the Catanians to change location, the city being indefensible between the

\footnotetext{
21 Ibid., 171. ["Son molti, che vogliono, che questa tal denominazione venga dal sito, e che per esser ella sotto il monte, ella si chiami così: perché Catana in greco vuol dir in lingua nostra, posta sotto l'alto."].

22 Ibidem. ["Una parte di questa città di Catanea è bagnata dal mare, l'altre son voltate verso le radici del monte Etna, sotto al quale ella è posta."].
} 
volcano and the sea ${ }^{23}$. The Catanian élite would then commit itself to build the walls ${ }^{24}$ at its own expense, and this appearance of city-fortress with the cannons on the ramparts emerges in the map.

A peaceful relationship with the volcano is completely restored through the emphasis on fertility. By retrieving what was possible from Fazello, and from those who had preceded him, the map repeats the myth of the Etnean fertility upon which the dedication had dwelled, with an overall celebration of the wholesomeness of the climate and the excellence of the cultivated fields and of the water. In the foreground four rivers (the canals) flow into the sea from beneath the walls; to the west cultivated fields and woods surround all the city and then spread at the foot of the volcano with the houses and the bell towers of the Etnean farmhouses. Fazello wrote:

The inhabitants divide the journey into three parts, or rather regions, namely, the foothills region, the wooded region and the open region, this latter being commonly defined as bare. The region which includes all the foothills of the mountain starts from Catania, and from the coast, and even reaches the monastery of St. Nicolò, whose friars belong to the Order of Saint Benedict [...] all that region is pleasant, adorned with beautiful vineyards, and all types of cultivated fruits of the earth, and the countryside there produces wonderful forage [...] The other region, which comes next on the mountain, is completely full of woods, and is almost ten miles long [...then] we entered in the third region of the mountain, which is called bare by the inhabitants because not only are there no woods nor any tree, but there is not any green grass, either ${ }^{25}$.

But what about the eruptions and the "fires" of Etna? The flame that comes out of the mouth of the volcano beyond the frame is there to remind us of them, with the surface made of lava which goes down towards the sea approaching the city walls from the north-east. It will be convenient to come back later to this representation of the north-eastern coast, which is here almost covered in and reshaped by the lava. Meanwhile it is necessary to retrieve the presence of Saint Agatha. The claim for her birth becomes, in relation to the threat represented by Etna, a essential element: to avert its destructive effects, Catania can count on the miraculous veil of the martyr. The Dominican scholar though not convinced of the Catanian origins of the saint - had no doubt about the effectiveness of the veil, this proving the success of its miraculous representation. All the history of the Etnean eruptions is a celebration of the protection of the saint. Fazello writes:

[...] in the year CCLIV, on February 1st, that is, two years after the death of Saint Agatha, Mount Etna throwing big fire balls, the Catanians ... moved by the religion, opened her

23 G.A. Filoteo degli Omodei, "Descrizione della Sicilia [1557], dal ms della Biblioteca Comunale di Palermo segn. Qq G 71", in G. Di Marzo, Biblioteca storica e letteraria di Sicilia, anastatic reprint Sala Bolognese 1974, Palermo, 1859-1886, vol. 25, 88-89; G. Capasso, "Il governo di don Ferrante Gonzaga in Sicilia", in Archivio Storico Siciliano, 1905, 462; Giarrizzo, La Sicilia dal Cinquecento all'Unità d'Italia, 158.

24 Giarrizzo, La Sicilia, 162.

25 Fazello, De Rebus Siculis, I, 2, 149-152. ["Gli abitatori dividono il viaggio in tre parti, o vero regioni, cioè piemontese, selvosa e aperta, la quale volgarmente si dice discoperta. La regione che abbraccia tutto il piè del monte (e però detta piemontese) comincia da Catania, e dalla riviera, ed arriva per fino al convento de' frati di S. Nicolò, che son dell'ordine di S. Benedetto [...] tutta quella regione è tutta amena, ornata di bellissime vigne, e d'ogni specie di frutti domestici, e le campagne che vi sono, producono biade bellissime [...] L'altra regione, che segue nel detto monte, è tutta piena di boschi, e dura quasi dieci miglia [... poi] entrammo nella terza regione del monte, chiamata dagli abitatori discoperta, ed è detta a questa foggia, perché non solamente non vi è selva alcuna, né alcun albero, ma non vi sono anche erbe verdi."]. 
sepulchre and, after taking the veil which covered her body, displayed it against the flames of the mountain. In doing so (which is a wonderful thing) the fire stopped immediately and, as if it had been scared by that veil, leaving the city of Catania, turned to somewhere else. Whence, because of this first event they had seen with their own eyes, the Catanians accepted the Christian faith and each time that Mount Etna would make some exceptional eruption, they would take out that veil, through which Catania was saved from the fire many times ${ }^{26}$.

But to make this protection believable it was necessary to establish that the young martyr belonged to the territory for certain; it was not possible, of course, to have her come from Palermo. All the subsequent journalism - Carrera, De Grossis, Colonna Romano ${ }^{27}$ - aims to secure the saint to Catania even pushing them to invent (Carrera) the document which would prove it ${ }^{28}$. By retrieving the very old mythology which connected Agatha with the eruption (this already being included in Pietro D'Argo's 9th century Epitafio ${ }^{29}$ ), this journalism expresses the defensio patriae carried out by Agatha in stopping the lava and, later, the political and military enemies against whom she pronounced the motto "noli offendere Patriam Agathae, quia ultrix iniuriarum est"30. They would not feel the need to reproduce other maps because Strizzia's map provided a model which has only to be confirmed. It is important, though, that the only engraving which is in Carrera's (picture 4) represents Mount Etna on whose sides there are Saint Agatha on the little elephant on the one side, and the elephant of the city on the other side, and along the foothills the "decora alta", from Ceres to Proserpina etc., of the old Catania.

In Stizzia's representation the urban topography would serve the purpose not only to bear witness to the "Locus martirij B. Agathae" or to the cathedral which celebrates her, but also to emphasize her origins with the identification of the "Domus Paterna B. Agathae" (which is indicated in the legend with the number 14).

The Saint, the volcano, the walls. Once these distinctive and summarizing elements have been outlined, the urban topography would provide a detailed description of the buildings and of the neighbourhoods of houses which are organized around two large roads which cut almost the whole

\footnotetext{
${ }^{26}$ Ibid., 159. ["nell'anno di nostra salute CCLIV, il primo di Febrajo, il che fu il secondo anno dopo la morte di Sant'Agata, gittando l'Etna molte gran palle di fuoco, i Catanesi ... spinti da religione, apersero il suo sepolcro, e pigliato il velo col quale era coperto il suo [di S. Agata, n.d.r.] corpo, lo portarono contra le fiamme del monte. Il che fatto (ch'è cosa meravigliosa) subito il fuoco mancò, e come s'egli avesse avuto paura di quel velo, lasciando la città di Catania, si rivolse in altra parte. Onde pigliando poi i Catanesi la fede di Cristo, per questa prima esperienza veduta, ogni volta che il monte Etna faceva qualche straordinario gittamento, essi cavavan fuori quel velo, per beneficio del quale Catania fu più volte liberata dal fuoco"].

27 P. Carrera, Delle memorie historiche della città di Catania, Catania, 1639; G.B. De Grossis, Agatha Catanensis, Catania, 1656; M. Colonna Romano, La vera deità catanesa, Verona, 1658.

${ }^{28}$ C. Crimi, "L'encomio "lacerato". A proposito di un apocrifo secentesco su S. Agata", in Synaxis, III, 1985, 387-412. Cf. also the review by G. Giarrizzo in Archivio Storico per la Sicilia Orientale, 1985-86, I-III, 491-493.

${ }^{29}$ Cf. C. Crimi, "L' Epitafio di Atanasio di Metone (BHG 196) di Pietro Vescovo d'Argo. Note al testo e all'interpretazione", in G. Spadaro, ed., Rapporti storici e letterari fra Sicilia e Grecia (IX-XIX sec.), Caltanissetta, 1998, 91-92.

30 Colonna Romano, La vera deità catanesa, 74 (The text has been anastatically reprinted with an introduction by M. Cosentino by Edizioni Boemi, Catania, not dated.
} 
map vertically, thus dividing it into two parts. The axonometric perspective organizes the topography into blocks: the buildings, except those out of scale (the cathedral, the castle, the "Curia civitatis"), are concentrated within blocks which draw geometrical figures (polygons, squares, rectangles, triangles) in the attempt to create symmetry in an irregular urban structure. The interplay of lines which draws acute and concave angles which face each other by curving or lining up the rows of façades is reprised and emphasized by the perimeter of the walls with its hollows and projections. Starting from the "Platea magna" (no. 26) the map seems to indentify its heart in the triangle whose vertex is given by the "Platea nuncupata la tririni" (no. 28) and the base by the line which unites the "Platea nuncupata San Filippo" (no. 29) with the "Platea magna" ("the plane of the grass" lying between them). The urban shape being thus rationalized, the elements which make the city "illustrissima antiquitate" can now find their place in the map. The list is longer than that of Rocca's map and if, at times, he would seem to follow Fazello, other times he would move away from him, as in the identification of the "Arcus vetustissimus" (no. 20), which is placed - almost so as to join two blocks - in what we have defined the heart of the city. Or in the indication of the "Termarum Monumenta" (no. 22) which Fazello had claimed no longer existed ${ }^{31}$. A quotation from Fazello is, though, the indication of the aqueduct "ex quadrate lapide" (no. 21) ${ }^{32}$ as well as the sepulchre of Stesichorus and the tower of the philosopher Empedocles.

Although the body of the city expands over the Etnean region (and totally covers it), the map shows how it clearly gravitates towards the sea, both with the prominence of the ramparts which almost repeat the layout of the gulf thus highlighting the inlet (which is closed by two out of scale buttresses) and with the port which projects its dock towards the centre of the gulf.

Twenty years after Lepanto the problem of the fortifications and of the Turkish threat, though still existing, has lost its strength: the view displays the line of the fortifications as having been completed, so as to almost show that the city has kept its promise, but it poses now another problem, that of the port. It is, therefore, necessary to shift the focus back onto the considerable lava flow which was referred to earlier which characterizes the north-eastern part of the map. Here the drawing, which almost illustrates Fazello's narrative ${ }^{33}$, solves the problem of the landing places of the coast which pushes towards Acireale's coastline, by showing how it was destroyed by the lava, and, in this way, it also settles the dispute for the port between Acireale and Catania in favour of Catania. Below the city the great gulf opens up with its sailing ships and its small boats which shuttle back and forth between them and the shore. The city claims its port to provide an outlet for the products of the Etnean region. The problem is solved in this way: the volcano, instead of representing a threat (the saint being there

\footnotetext{
31 Fazello, De Rebus Siculis, I, 3, 134.

32 Ibidem.

33 Ibid., 135.
} 
to protect the city), is a source of wealth; the city is well fortified, it is necessary to provide it with a real port.

Picture 4. Catanae Decora Alta Vetustae, s.a. e s.d., in P. Carrera, Delle memorie historiche della città di Catania, Catania 1639, incisione su rame, mm 280x175

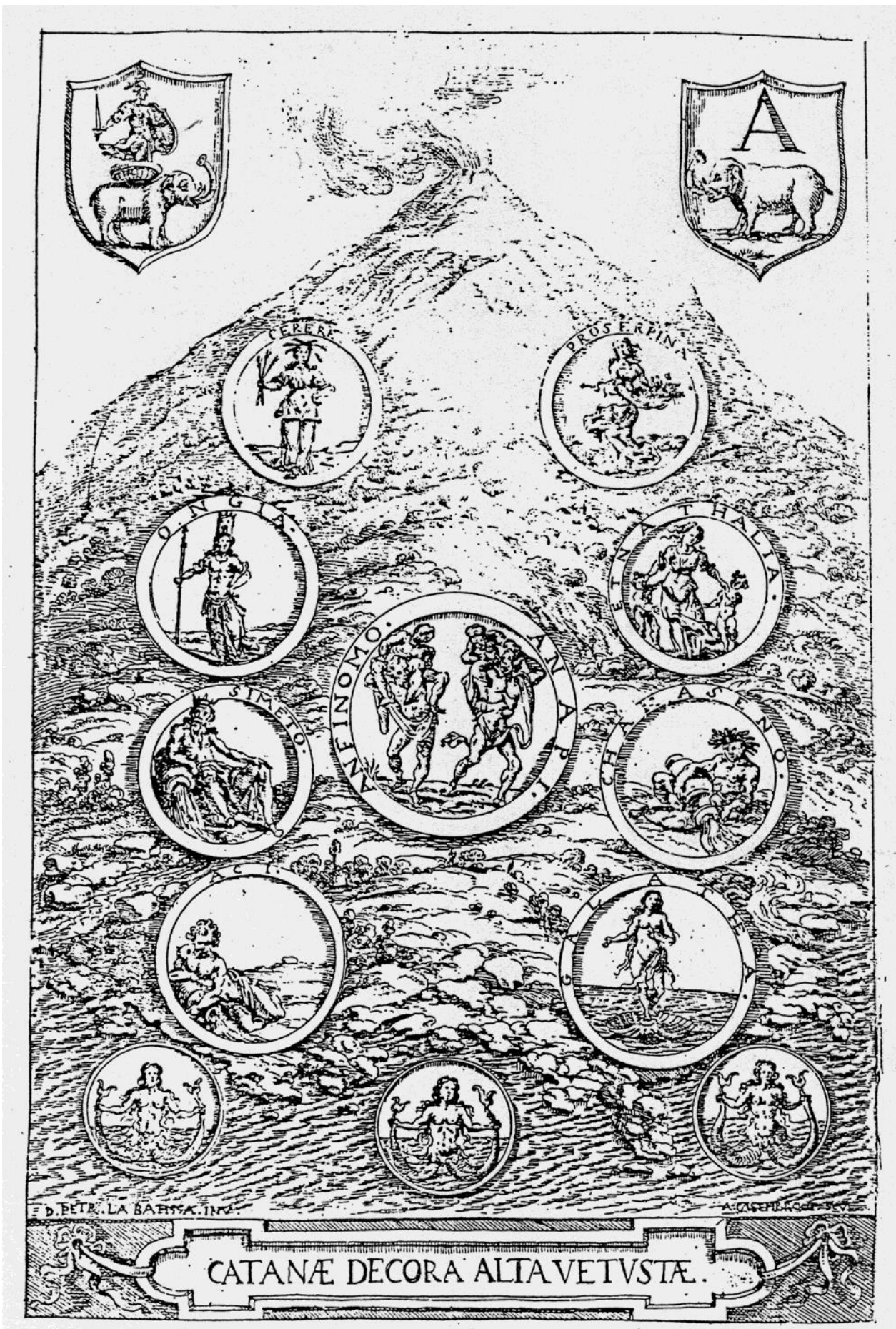


Stizzia's model, which was adopted by the great Dutch cartography, will circulate across Europe and, therefore return to Catania stronger, it being destined to be imitated and reproduced for a long time, well beyond the 18th century. In 1690 Francesco Privitera will write again that the map "well made by the noble Stizzia goes around" 34 .

A few years after the publication of the view of Catania in the Civitates orbis terrarum, other cartographic representations would be added to the list of the images of Catania.

Already from the first decades of the 16th century the European cities would start to provide themselves, not only with celebratory views, but also with urban maps with practical purposes of a military nature: the planimetric mapping - especially of the fortified constructions - would start to spread.

As for Catania the most significant 16th century plans are those by Spannocchi ${ }^{35}$ and Camiliani $^{36}$. Both architects, in different years, would aim to design the fortifications of the Sicilian coasts. Both of them, though, besides the drawings of a merely practical nature, would produce two views in which the city outline is inserted, once again, between the sea and the mountain. The techniques of representation are completely different, but the view of the city under the volcano is still dominating.

Unlike the view in the Civitates Orbis Terrarum, that by Spannocchi of 1578 (picture 5) is reprised from a real point of view, such as it appeared to the traveller who reached it from the south; as Spannocchi would write: "The perspective of every place and of the towers which presently exist and which can be observed faithfully painted has been reprised..."37.

As Pagnano has noted, the view is divided in an almost geometrical way ${ }^{38}$. The outline of the city divides the map into two symmetrical areas: at the top, the outline of the volcano, which is matched by the void of the clear sky where the title "Catania" stands out. At the bottom the plenum of the countryside, which is separated from the sea by a line of dunes - whose vanishing point is the top of the volcano. The city is almost "divided" into a "marine" part and a "terrestrial" part; this being an image which, once again, refers back to Fazello and which is destined to last up until the 18th century, when it will be reintroduced by Biscari, who would imagine the traveller crossing Catania "from the

\footnotetext{
${ }^{34}$ F. Privitera, Annuario catanese, Catania, 1690, 68. [“ben attesa dal nobile Stizzia camina in giro.”].

35 T. Spannocchi, Descripcion de las Marinas de todo el Reino de Sicilia... MDXCVI, mss. 788, National Library of Madrid (anastatic reprint of the Association of Architects of Catania, edited by R. Trovato, Marine del Regno di Sicilia, Milano, 1993.

36 C. Camiliani, "Descrizione della Sicilia", in G. Di Marzo, Biblioteca storica e letteraria di Sicilia, anastatic reprint Sala Bolognese 1974, Palermo, 1859-1886, vol. 26. On Camiliani, s. F. Negri Arnoldi, "Camilliani Camillo", in Dizionario Biografico degli Italiani, vol. XVII, 1974, 214-217, and M. Scarlata, ed., L'opera di Camillo Camilini, Roma, 1993.

37 Spannocchi, Descripcion, 5r. [“è stata ripresa la prospettiva di ogni luogo e delle torri che attualmente esistono e che si potranno osservare dipinte fedelmente...”].

38 Pagnano, Il disegno delle difese, 35.
} 
most important parts of the City to the lower and marine part"39. At the centre of the countryside (which is represented with trees and with a sketch of the line of orchards, so as to almost graphically express what Spannocchi would define "the great fertility of the fields"), in the foreground, the ancient "Theatre" stands out.

Picture 5. Catania, in T. Spannocchi, Descripcion de las Marinas de todo el Reino de Sicilia..., 1596, disegno a penna con velature di acquerello, mm 309x104 (Biblioteca Nacional - Madrid)

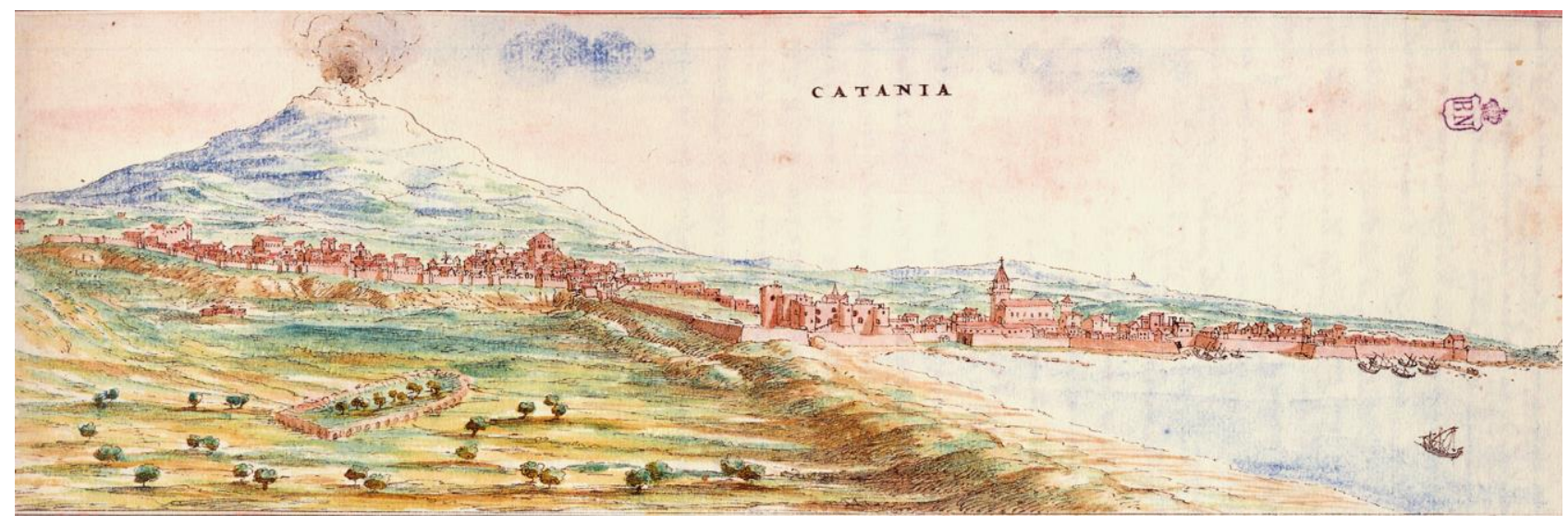

Because of the "low" point of view, the city is drawn almost with a sky-line in which, beyond the wall, the same architectonic elements which are found in the Civitates Orbis Terrarum stand out: the cathedral with its high bell tower (which is a very important lookout post for Spannocchi ${ }^{40}$ ), the Ursino Castle, the tower of Don Lorenzo Gioeni.

The volcano, the vestiges of the ancient times, the fertile fields, the urban architectonic elements all play a role in the definition of the image of the city. However, the representation of the ample inlet full of ships reappears in Spannocchi: in his text he would complain that a city of "mucha consideracion" "non tiene Puerto ny tiene abrigo para Navios"41. To emphasize the success of the bond volcano-saint-city, the Sienese architect would end the list of the "virtues" of Catania by stating that "it is the homeland of the famous Virgin and Martyr Saint Agatha, whose devotion numbers many miracles and generates a great flow of people" 42 .

\footnotetext{
${ }^{39}$ I. Paternò Castello, Viaggio per tutte le antichità della Sicilia, Napoli, 1781, 33. ["dalle parti più eminenti della Città alla parte più bassa, e marittima"].

40 Spannocchi, Descripcion, XI.

${ }^{41}$ Ibid., XII.

42 Ibidem. (translation in G. Pagnano, Il disegno delle difese, 136). [“è patria della famosa Vergine e Martire Sant’Agata, la cui devozione si vanta di molti miracoli e genera un grande afflusso di gente."].
} 
In 1584 (the same year of Rocca's visit) Camiliani would copy Fazello ${ }^{43}$ in his description and repropose, in part, the same elements in his view. If the practical and military aims of the two works and the reduced height of the point of view on the horizon are the same, the position of the designer is different. The city is, once again, seen from the sea, though from a very rare eastern perspective. This perspective option not only makes the image of the city more effective (almost as if it were actually being looked at from a ship), but also it cancels out the representation of the surrounding territory, thus emphasizing the overlooking presence of the volcano (picture 6).

Picture 6. Prospe[tti]va di Catania città, [seconda metà XVI sec.], in C. Camilliani, Descrizione della Sicilia, [1584 ca], disegno su carta

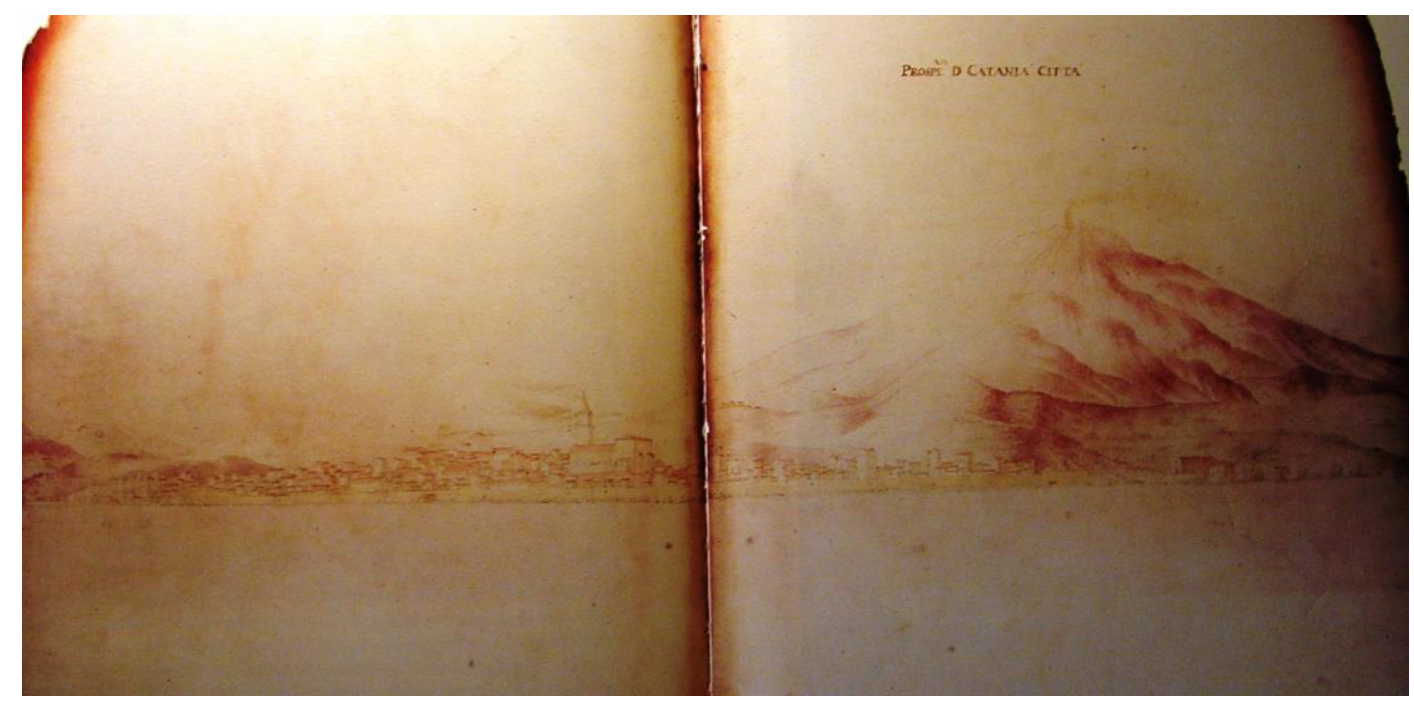

If also the military engineers Spannocchi and Camiliani would insist on representing Catania with Mount Etna, it's because the model of the city under the volcano was, by then, definitively accepted. And the image is positive.

To change this "happy" relationship, though, a tragic event would occur in the 17th century: the eruption of 1669, which would contribute to reshape the landscape, the city and its representation.

\section{CONCLUSIONS}

In a non-generic way, the cartographic story we have told reveals the relationship between representation and urban reality. In this case the relationship is essentially political, as it visually expresses the identity on which the élites of Catania bet on at the end of sixteenth century.

\footnotetext{
43 "Una parte di Catania è bagnata dal mare, e le altre son volte verso le radici del monte, sotto al quale vi è posta... e per essere quella sotto il monte ella si chiama così, perché Catania in greco vuol dire in lingua nostra posta sotto l'alto" ("One part of this city of Catania is on the sea, the others face the foothills of Mount Etna, under which it is placed... and it is called like that because it is placed under the mountain: because the Greek word Catana means placed under the top in our language") (Camiliano, Descrizione della Sicilia, 322).
} 
Reassured by the victory of Lepanto, Catania, and Sicily in general, was preparing to relaunch its role in the Mediterranean again center of trade and crossing of civilizations, not only as a military outpost, representing itself assolid and cohesive point of opening in a region rich thanks to the "prodigious" fertility of the Etnean land.

These are the years when vineyards expand, in competition with the pastures that will eventually see wine win. However, these are also the years in which the city rediscovers a balance of power with the Count-Bishop. The maps make a "wish" (the port) rather than a reality, but it is a wish that materialises as a strong work of identity for the city during the Early Modern Age. Having already surpassed the dramatic and tragic period of the eruption of 1669 and, most especially, the earthquake of 1693, this concept comes up again strongly as one of the original aspects of its history. Stizzia's map describes and defines, with the effectiveness of the rhetoric of "seeing", this feature and entrusts it to posterity. 